\title{
Effects of Exercise, Diet, and a Combination of Exercise and Diet in Overweight and Obese Adults - A Meta-Analysis of the Data
}

\author{
Bettina Schaar ${ }^{1}$, Corinna Moos-Thiele ${ }^{*, 1}$ and Petra Platen ${ }^{2}$ \\ ${ }^{1}$ Institute of Rehabilitation and Sport for the Disabled, German Sport University Cologne, Germany \\ ${ }^{2}$ Department of Sports Medicine and Sports Nutrition, Faculty of Sports Science, Ruhr University Bochum, Germany
}

\begin{abstract}
The objective of the following meta-analysis was to determine what kind of treatment, or combination of treatments, has the greatest effect on weight loss in overweight and obese adults.

A systematic search was conducted of the available literature published between 1993 and 2006 that covered randomized controlled trials on overweight and obese subjects who underwent treatment consisting of physical exercise and/ or changes in diet. The scope of the search thus incorporated seven relevant databases.

Using 6,545 key word combinations, the electronic search yielded a total of 36,869 abstracts. 13 relevant studies with a total of 826 subjects (BMI $>25 ; 17-68$ years of age) met the meta-analysis criteria. The courses of treatment included "diet (d)", "physical exercise (pe)", "diet and physical exercise (dpe)", and "no intervention (ni)". The results confirmed the hypothesis that the combined intervention "dpe" had the greatest effect with regard to weight loss. The single treatments "pe" and "d" also led to weight loss, with "d" having a significantly greater effect than "pe".

The main reason for the small sample size of thirteen studies out of 36,819 was that the experimental design and/or procedures of most studies were inadequate. A common error was a failure to assign subjects randomly to the different treatment groups. The results of our meta-analysis indicate that a combination of diet and physical exercise is the best form of treatment to induce weight loss in overweight individuals in the first weeks, followed by physical exercise to maintain weight loss.
\end{abstract}

Keywords: Overweight, obesity, physical activity, diet, adult.

\section{INTRODUCTION}

Excess weight and obesity and the resulting risk factors are major contributing factors to skyrocketing health-care costs. Between 3.9 and 10.33 billion euros are spent in Germany each year on treating obesity, which can lead to serious health problems such as diabetes, hypertension, and coronary heart disease. In a study incorporating data from medical examinations of men born in 1974 routinely conducted to assess fitness for military service, the German Federal Ministry of Health found that 154 out of 1000 men were slightly to moderately overweight and 15 were severely obese [1]. The prevalence of obesity has also increased dramatically in the U.S. during the last decade. An estimated 97 million American adults are overweight or obese, making obesity the nation's second most common cause of preventable death [2].

\section{REVIEW OF REVIEWS}

Before an evaluation of a new meta-analysis, a review of established meta-analyses is used to show the necessity of an additional evaluation. The questioning of the review of reviews amounted to the investigation of meta-analyses, which evaluated the effects of dietary advices and or exercise

*Address correspondence to this author at the German Sport University Cologne, Am Sportpark Müngersdorf 6, D-50933 Cologne, Germany; Tel: ++49-173-5195471; Fax: ++49-221-49827460; E-mail: comoos@freenet.de interventions for obese subjects. The search of the secondary review took place in seven selected databases: Cochrane Reviews der Cochrane Library, Digital Dissertations, EMBASE, MEDLINE, Psycinfo, Psyndex und SPORT Discus. As result of the research, 22 publications could be identified in the following journals: Advances in Therapy, British Journal of Nutrition, Coronary Artery Disease, The Cochrane Collaboration, European Journal of Clinical Nutrition, Exercise and Sport Sciences Reviews, Health Technology Assessment, International Journal of Obesity, Journal of the American Dietetic Association, Journal of the American College of Nutrition, The Journal of the American Osteopathic Association, Journal of Human Nutrition and Dietetics, Journal of Science and Medicine in Sport, Journal of Sports Medicine, Medicine \& Science in Sports \& Exercise, Obesity Reviews und Official Journal of the American College of Sports Medicine. The precise inspection of the reviews showed that one health technology assessment [3], 15 meta-analyses [4-18] and six descriptive reviews [1924] were detected. Further consideration resulted in the exclusion of the descriptive reviews. In total, six to 70 studies in one publication with 41 to 123,423 subjects were included. The samples had a mean age of older than 18 years and the mean BMI was higher than $25 \mathrm{~kg} / \mathrm{m}^{2}$, except for the controls which had normal BMIs $\left(<25 \mathrm{~kg} / \mathrm{m}^{2}\right)$. The treatments of the studies lasted from one day to 90 weeks. Table 1 shows all included reviews during 1993 and 2006. The results of the review of reviews showed that the search 
Table 1. Meta-Analyses During the Time Period of 1993 to $2006(k=14)$

\begin{tabular}{|c|c|c|c|c|c|c|c|}
\hline $\begin{array}{c}\text { Author/ } \\
\text { Year of } \\
\text { Publication }\end{array}$ & $\begin{array}{c}\text { Superior } \\
\text { Treatment, } \\
\text { Study - k } \\
\text { (Subjects - n) }\end{array}$ & $\begin{array}{c}\text { Age } \\
\text { (Years) }\end{array}$ & $\begin{array}{c}\text { KG } \\
(\mathbf{k g}) \\
\text { BMI } \\
\left(\mathbf{k g} / \mathbf{m}^{2}\right)\end{array}$ & $\begin{array}{c}\text { Duration of } \\
\text { Treatment } \\
\text { and } \\
\text { Dropout }\end{array}$ & $\begin{array}{c}\text { Databases/ } \\
\text { Period of Time }\end{array}$ & Method & Conclusion \\
\hline \multicolumn{8}{|c|}{ Only Diets, Nutrition Replacements, Medication or Surgeries } \\
\hline $\begin{array}{l}\text { Anderson et } \\
\text { al., 2004 [3] }\end{array}$ & $\begin{array}{c}\text { no i. } \\
\mathrm{I}_{1}: \text { meal } \\
\text { replacements: } 4 \\
(579) \\
\mathrm{I}_{2}: \text { energy- } \\
\text { restricted diets (to } \\
1500 \mathrm{kcal} / \mathrm{d}): 6 \\
(200) \\
\mathrm{I}_{3}: \text { low energy diets } \\
(800 \text { to } 1500 \\
\text { kcal/d): } 10(365) \\
\mathrm{I}_{4}: \text { very low energy } \\
\text { diets } \\
(<800 \mathrm{kcal} / \mathrm{T}): 19 \\
(1,968) \\
\mathrm{I}_{5}: \text { soy very low } \\
\text { energy diets }(800 \\
\text { kcal/T } \\
\text { Sojaprodukte): } 8 \\
(333)\end{array}$ & $>20$ & $\begin{array}{l}>25 \\
\mathrm{~kg} / \mathrm{m}^{2}\end{array}$ & $\begin{array}{l}8-24 \text { weeks } \\
11-47 \text { hours } \\
\text { directly } \\
\text { supported by } \\
\text { the } \\
\text { physician, } \\
\text { lessons took } \\
\text { part in the } \\
\text { clinic } \\
\text { Dropout: } \\
0-73 \%\end{array}$ & $\begin{array}{l}1 \text { DB (Medline and } \\
\text { handsearch) } \\
1980 \text { to } 2001\end{array}$ & $\begin{array}{l}\text { M: random } \\
\text { effects model }\end{array}$ & $\begin{array}{l}\text { Meal replacements and energy- } \\
\text { restricted diets seem to have the } \\
\text { same effects, low energy diets and } \\
\text { very low energy diets show the } \\
\text { greatest body weight reduction } \\
\text { after } 24 \text { weeks, soy very low } \\
\text { energy diets have after } 8 \text { weeks } \\
\text { the highest weight reduction. }\end{array}$ \\
\hline $\begin{array}{c}\text { Avenell } \\
\text { et al., } 2004 \\
{[4]}\end{array}$ & $\begin{array}{c}26 \text { (no i.) } \\
\mathrm{I}_{1}: \text { low-fat diet } \\
\mathrm{I}_{1}: \text { low-calorie diet } \\
\mathrm{I}_{2}: \text { very low-calorie } \\
\text { diet } \\
\mathrm{I}_{3}: \text { protein sparing } \\
\text { modified fasts }\end{array}$ & $>18$ & $\begin{array}{l}>28 \\
\mathrm{~kg} / \mathrm{m}^{2}\end{array}$ & $\begin{array}{l}12 \text { month - } \\
5 \text { years } \\
\text { Dropout: } \\
0-40 \%\end{array}$ & $\begin{array}{l}13 \text { DB (Medline, } \\
\text { Embase, Biosis, } \\
\text { CAB Nutrition } \\
\text { Abstracts and } \\
\text { Reviews, CCTR, } \\
\text { PsycInfo, Science } \\
\text { Citation Index, } \\
\text { British Library } \\
\text { Inside, CINAHL, } \\
\text { HealthSTAR, } \\
\text { AMED, } \\
\text { SPORTDiscus, UK } \\
\text { National Research } \\
\text { Register and } \\
\text { handsearch) } \\
1966 \text { to } 05 / 2001\end{array}$ & $\begin{array}{l}\text { M: fixed effect } \\
\text { model }\end{array}$ & $\begin{array}{l}\text { Low-fat diets show the greatest } \\
\text { weight reduction. Little evidence } \\
\text { supports the use of the other diets } \\
\text { in obese adults. Long-term } \\
\text { follwo-up in RCTs is needed to } \\
\text { evaluate further effects. }\end{array}$ \\
\hline $\begin{array}{c}\text { Douketis } \\
\text { et al., } 2005 \\
{[5]}\end{array}$ & $\begin{array}{c}44(19,273) \\
\mathrm{I}_{1}: \operatorname{diet}: 16(5,698) \\
\mathrm{I}_{2}: \text { medication: } 19 \\
(9,953) \\
\mathrm{I}_{3}: \text { surgery: } 9 \\
(3,622)\end{array}$ & $\begin{array}{l}\text { D: } \\
40-59 \\
\text { M: } \\
40-58 \\
\text { S: } \\
34-49\end{array}$ & $\begin{array}{l}\text { D: } 78- \\
116 \mathrm{~kg} \\
\text { M: } 87- \\
102 \mathrm{~kg} \\
\text { S: } 110- \\
142 \mathrm{~kg}\end{array}$ & $\begin{array}{c}\text { D: } 3-18 \\
\text { month } \\
\text { weight- } \\
\text { reduction } \\
\text { and } 12-36 \\
\text { month } \\
\text { weight } \\
\text { stabilisation } \\
\text { M: after } 1 \text { to } \\
2 \text { years } \\
\text { S: after } 2 \text { to } \\
3 \text { years } \\
\text { Dropout: } \\
\text { no i. }\end{array}$ & $\begin{array}{c}3 \text { DB (Medline, } \\
\text { Healthstar, CCTR } \\
\text { and handsearch) } \\
1966 \text { to } 09 / 2003\end{array}$ & $\begin{array}{l}\text { M: random } \\
\text { effects model }\end{array}$ & $\begin{array}{l}\text { Diets reduced the body weight } \\
\text { after } 2 \text { to } 4 \text { years by } 5 \mathrm{~kg} ; \\
\text { medication after } 1 \text { to } 2 \text { years by } 5 \\
\text { to } 10 \mathrm{~kg} \text { and sugeries after } 2 \text { to } 4 \\
\text { years by } 25 \text { to } 75 \mathrm{~kg} \text { body weight. }\end{array}$ \\
\hline $\begin{array}{c}\text { Schrauwen } \\
\& \\
\text { Westerterp, } \\
2000[6]\end{array}$ & $\begin{array}{c}\text { no i. } \\
\mathrm{I}_{1}: \text { high-fat diet: } \\
\text { no } \mathrm{i} . \\
\mathrm{I}_{2}: \text { low-fat diet: } \\
\text { no i. }\end{array}$ & no i. & $\begin{array}{c}\text { alle } \\
\text { Gewicht } \\
\text { sklassen }\end{array}$ & $\begin{array}{c}\text { 1-9 days } \\
\text { dropout: no i. }\end{array}$ & no i. & M: no i. & $\begin{array}{l}\text { High-fat diets lead to the } \\
\text { development of obesity. The } \\
\text { compareson of high-fat and low- } \\
\text { fat diets shows that high-fat diets } \\
\text { produce positive leptin levels. A } \\
\text { body weight reduction is } \\
\text { impossible. }\end{array}$ \\
\hline
\end{tabular}


(Table 1) contd....

\begin{tabular}{|c|c|c|c|c|c|c|c|}
\hline $\begin{array}{c}\text { Author/ } \\
\text { Year of } \\
\text { Publication }\end{array}$ & $\begin{array}{c}\text { Superior } \\
\text { Treatment, } \\
\text { Study - k } \\
\text { (Subjects - n) }\end{array}$ & $\begin{array}{c}\text { Age } \\
\text { (Years) }\end{array}$ & $\begin{array}{c}\text { KG } \\
(\mathrm{kg}) \\
\text { BMI } \\
\left(\mathrm{kg} / \mathrm{m}^{2}\right)\end{array}$ & $\begin{array}{l}\text { Duration of } \\
\text { Treatment } \\
\text { and } \\
\text { Dropout }\end{array}$ & $\begin{array}{l}\text { Databases/ } \\
\text { Period of Time }\end{array}$ & Method & Conclusion \\
\hline \multicolumn{8}{|c|}{ Diet and Physical Activity } \\
\hline $\begin{array}{c}\text { van Baak, } \\
1999 \text { [7] }\end{array}$ & $\begin{array}{c}\text { no i. } \\
\mathrm{I}_{1}: \text { diet: no i. } \\
\mathrm{I}_{2} \text { : diet and } \\
\text { physical activity: } \\
\text { no } \mathrm{i} \text {. }\end{array}$ & $>18$ & $\begin{array}{l}>25 \\
\mathrm{~kg} / \mathrm{m}^{2}\end{array}$ & $\begin{array}{c}12 \text { weeks } \\
\text { dropout: no i. }\end{array}$ & no i. & M: no i. & $\begin{array}{l}\text { The meta-analysis gives no clear } \\
\text { answer to the question whether } \\
\text { exercise training increases fat } \\
\text { utilization at rest, during exercise } \\
\text { or over } 24 \mathrm{~h} \text { in obese subjects. }\end{array}$ \\
\hline $\begin{array}{c}\text { Curioni \& } \\
\text { Lourenço, } \\
2005[8]\end{array}$ & $\begin{array}{c}6(407) \\
\mathrm{I}_{1}: \text { diet: } 6(142) \\
\mathrm{I}_{2}: \text { diet and } \\
\text { physical activity: } 6 \\
(265)\end{array}$ & $21-65$ & $\begin{array}{c}>25 \\
\mathrm{~kg} / \mathrm{m}^{2} \\
83.5- \\
106.0 \\
\mathrm{~kg}\end{array}$ & $\begin{array}{l}\text { Intervention: } \\
\text { 10-52 weeks } \\
\text { follow-Up: } \\
\text { 12-24 month } \\
\text { dropout: 9- } \\
24 \%\end{array}$ & $\begin{array}{l}3 \text { DB (CCTR, } \\
\text { Medline, Lilacs) } \\
\text { until 03/2003 }\end{array}$ & $\begin{array}{l}\text { M: fixed effect } \\
\text { model und } \\
\text { Mantel } \\
\text { Haenszel odds } \\
\text { ratio }\end{array}$ & $\begin{array}{l}\text { Interventions with diet and } \\
\text { physical activity reduced body } \\
\text { weight by } 20 \% \text { more than the } \\
\text { intervention only diet. This is } \\
\text { partially sustained after } 1 \text { year. } \\
\text { But also half of all subjects } \\
\text { gained weight after } 1 \text { year. }\end{array}$ \\
\hline $\begin{array}{c}\text { Garrow \& } \\
\text { Summerbell } \\
, 1995[9]\end{array}$ & $\begin{array}{c}28 \\
\mathrm{I}_{1}: \text { diet: no i. } \\
\mathrm{I}_{2}: \text { diet and } \\
\text { physical activity: } \\
\text { no i. }\end{array}$ & $>18$ & $\begin{array}{l}25-38 \\
\mathrm{~kg} / \mathrm{m}^{2}\end{array}$ & $\begin{array}{l}\text { 3-52 weeks } \\
\text { dropout: no i. }\end{array}$ & $\begin{array}{c}1 \text { DB (Medline and } \\
\text { handsearch) } \\
1966 \text { to } 1993\end{array}$ & M: no i. & $\begin{array}{l}\text { Aerobic exercise causes a modest } \\
\text { loss in weight without dieting. } \\
\text { Exercise provides some } \\
\text { conservation of fat free mass } \\
\text { during weight loss by dieting, } \\
\text { probably in part by maintaining } \\
\text { glycogen and water. }\end{array}$ \\
\hline \multicolumn{8}{|c|}{ Only Physical Activity } \\
\hline $\begin{array}{l}\text { Blundell \& } \\
\text { King, 1999 } \\
\text { [10] }\end{array}$ & $\begin{array}{c}70 \text { (no i.) } \\
\mathrm{I}_{1}: \text { high intensity } \\
\text { training with } \\
\mathrm{I}_{2}: \text { moderate } \\
\text { intensity training } \\
\mathrm{I}_{3}: \text { controlls } \\
\text { each with nutrition } \\
\text { protocols }\end{array}$ & $>18$ & $\begin{array}{c}\text { all } \\
\text { weights }\end{array}$ & $\begin{array}{l}1 \text { day to } 44 \\
\text { weeks } \\
\text { dropout: } \\
\text { no i. }\end{array}$ & no i. & M: no i. & $\begin{array}{l}\text { Evidence suggests that a high } \\
\text { level of physical activity can aid } \\
\text { weight control. This effect } \\
\text { accrues either because of } \\
\text { improving the matching of food } \\
\text { intake to energy expenditure } \\
\text { (regulation) or by raising } \\
\text { expenditure so that it is difficult } \\
\text { for people to eat themselves into a } \\
\text { positive energy balance. }\end{array}$ \\
\hline $\begin{array}{l}\text { Miller et al., } \\
1997 \text { [11] }\end{array}$ & $\begin{array}{c}493 \text { (no i.) } \\
\mathrm{I}_{1}: \text { diet: no i. } \\
\mathrm{I}_{2}: \text { physical activity: } \\
\text { no i. } \\
\mathrm{I}_{3}: \text { diet and physical } \\
\text { activity: no i. }\end{array}$ & $\begin{array}{c}18-68 \\
40.0 \pm 0.5 \\
36.5 \pm 1.4 \\
39.5 \pm 0.7\end{array}$ & $\begin{array}{c}22-60 \\
\mathrm{~kg} / \mathrm{m}^{2} \\
34.9 \pm 0.6 \\
26.4 \pm 1.5 \\
34.8 \pm 1.0\end{array}$ & $\begin{array}{l}\text { 2-90 weeks } \\
\text { dropout: } \\
\text { no i. }\end{array}$ & $\begin{array}{l}1 \text { DB (Medline) } \\
1969 \text { to } 1994\end{array}$ & $\begin{array}{l}\text { ANOVA and } \\
\text { Student- } \\
\text { Neuman-Keul } \\
\text { test }\end{array}$ & $\begin{array}{l}\text { The population was very narrowly } \\
\text { focussed on middle aged subjects } \\
\text { that are only moderately obese. The } \\
\text { interventions lasted for only short } \\
\text { periods of time. Obese subjects } \\
\text { profit from a treatment with "only } \\
\text { physical activity" as well as from a } \\
\text { treatment with "physical activity and } \\
\text { diet" in evidence by body weight } \\
\text { reduction and maintained loss after } 1 \\
\text { year. }\end{array}$ \\
\hline $\begin{array}{c}\text { Ross, } 1997 \\
{[12]}\end{array}$ & $\begin{array}{c}\text { no i. }(309) \\
\mathrm{I}_{1}: \text { diet: } 8 \text { (205) } \\
\mathrm{I}_{2}: \text { physical activity: } \\
2(41) \\
\mathrm{I}_{3}: \text { diet and physical } \\
\text { activity: } 3 \text { (63) }\end{array}$ & $>18$ & no i. & $\begin{array}{l}2 \text { weeks to } \\
14 \text { month } \\
\text { dropout: no } \\
\text { i. }\end{array}$ & no i. & M: no i. & $\begin{array}{l}\text { Changes in waist circumference and } \\
\text { sagittal diameter are well correlated } \\
\text { with corresponding changes in } \\
\text { visceral adipose tissue. Effects of } \\
\text { diet- and exercise-induced weight } \\
\text { loss on visceral adipose tissue from } \\
\text { well controlled studies are required } \\
\text { to advance current knowledge with } \\
\text { respect to the effects of diet and } \\
\text { exercise on the adipose tissue depot } \\
\text { that conveys the greatest healteh } \\
\text { risk. Evidence is not validated } \\
\text { because of the small size of } \\
\text { treatment groups. }\end{array}$ \\
\hline $\begin{array}{l}\text { Ross et al., } \\
2000 \text { [13] }\end{array}$ & $\begin{array}{c}8(496) \\
\mathrm{I}_{1}: \operatorname{diet}: 8(244) \\
\mathrm{I}_{2}: \text { physical activity: } \\
8(252)\end{array}$ & $>18$ & $\begin{array}{l}>25 \\
\mathrm{~kg} / \mathrm{m}^{2}\end{array}$ & $\begin{array}{l}\text { 10-52 weeks } \\
\text { (17-65 } \\
\text { min/day } \\
\text { added } \\
\text { exercise }) \\
\text { dropout: no } \\
\text { i. }\end{array}$ & no i. & M: no i. & $\begin{array}{l}\text { Daily exercise of about } 30 \text { to } 60 \\
\text { minutes produces weight loss. This } \\
\text { suggests that exercise without diet } \\
\text { restriction is an effective strategy for } \\
\text { reducing obesity and related co- } \\
\text { morbidities. As the sports form, the } \\
\text { authors suggest walking. }\end{array}$ \\
\hline
\end{tabular}


(Table 1) contd.....

\begin{tabular}{|c|c|c|c|c|c|c|c|}
\hline \multicolumn{8}{|c|}{ Only Physical Activity } \\
\hline Wing, 1999 & $\begin{array}{c}15(1,644) \\
\mathrm{I}_{1}: \text { physical } \\
\text { activity: } 10(428) \\
\mathrm{I}_{2}: \text { controlls: } 10 \\
(362) \\
\mathrm{I}_{3}: \text { diet: } 13 \text { (402) } \\
\mathrm{I}_{4}: \text { diet and aerobic } \\
\text { physical activity: } \\
13 \text { (402) } \\
\mathrm{I}_{5}: \text { diet and } \\
\text { strength training: } 4 \\
(50)\end{array}$ & no i. & $\begin{array}{l}>25 \\
\mathrm{~kg} / \mathrm{m}^{2}\end{array}$ & $\begin{array}{l}\text { 4-12 month } \\
\text { Dropout: } \\
\text { no i. }\end{array}$ & no i. & M: no i. & $\begin{array}{l}\text { The meta-analysis consistently } \\
\text { shows benefits of exercise for } \\
\text { weight loss, but the effects are } \\
\text { often modest. These effects may } \\
\text { result from small sample sizes, } \\
\text { short study duration, and poor } \\
\text { adherence to the exercise } \\
\text { prescriptions. Better ways of } \\
\text { measuring exercise and promoting } \\
\text { adherence to exercise are } \\
\text { necessary for a detailed } \\
\text { description of the doses and types } \\
\text { of exercise, which promote long- } \\
\text { term weight loss. }\end{array}$ \\
\hline \multicolumn{8}{|c|}{ Diet, Physical Activity and Behavior Therapy } \\
\hline $\begin{array}{l}\text { Avenell et } \\
\text { al., 2004a }\end{array}$ & $\begin{array}{c}27(6,834) \\
\text { diet and: } \\
\mathrm{I}_{1}: \text { medic: } 8 \\
\mathrm{I}_{2}: \text { physical } \\
\text { activity: } 5 \\
\mathrm{I}_{3}: \text { behavior } \\
\text { therapy: } 4 \\
\mathrm{I}_{4}: \text { behavior } \\
\text { therapy and } \\
\text { physical activity: } 7\end{array}$ & $>18$ & $\begin{array}{c}>25 \\
\mathrm{~kg} / \mathrm{m}^{2}\end{array}$ & $\begin{array}{c}\text { 12-60 month } \\
\text { Dropout: } \\
5-64 \%\end{array}$ & $\begin{array}{l}13 \text { DB (Medline, } \\
\text { Embase, Biosis, } \\
\text { CAB Nutrition } \\
\text { Abstracts and } \\
\text { Reviews, CCTR, } \\
\text { PsycInfo, Science } \\
\text { Citation Index, } \\
\text { British Library } \\
\text { Inside, CINAHL, } \\
\text { HealthSTAR, } \\
\text { AMED, } \\
\text { SPORTDiscus, UK } \\
\text { National Research } \\
\text { Register and } \\
\text { handsearch) } \\
1966 \text { to 05/2001 }\end{array}$ & $\begin{array}{l}\text { M: fixed effect } \\
\text { model }\end{array}$ & $\begin{array}{l}\text { Adding orlistat, sibutramine, } \\
\text { exercise, or behavior modification } \\
\text { to dietary advice can improve } \\
\text { long-term weight loss. The } \\
\text { greatest weight loss resulted from } \\
\text { the combination of behavior } \\
\text { modification or sibutramine and } \\
\text { dietary advice. However, the other } \\
\text { combinations resulted in } \\
\text { additional weight loss after } 12 \\
\text { months. Furthermore, } 36 \text { months } \\
\text { of behavior modification and } \\
\text { dietary advice caused additional } \\
\text { weight reduction. }\end{array}$ \\
\hline \multicolumn{8}{|c|}{ Diet and Physical Activity Follow-Up } \\
\hline $\begin{array}{c}\text { Fogelholm } \\
\& \\
\text { Kukkonen- } \\
\text { Harjula, } \\
2000\end{array}$ & $\begin{array}{c}31(123,423) \\
\mathrm{I}_{1}: \text { physical activity } \\
\text { and weight gain } \\
\mathrm{I}_{2}: \text { Jojo-Effect after } \\
\text { weight reduction } \\
\text { by diet } \\
\mathrm{I}_{3}: \text { Jojo-Effect after } \\
\text { weight reduction } \\
\text { by physical } \\
\text { activity }\end{array}$ & $18-64$ & $\begin{array}{l}>25 \\
\mathrm{~kg} / \mathrm{m}^{2}\end{array}$ & $\begin{array}{l}15 \text { weeks to } \\
21 \text { years } \\
\text { Dropout: } \\
\text { no i. }\end{array}$ & $\begin{array}{c}\text { no i. } \\
1980 \text { to } 2000\end{array}$ & M: no i. & $\begin{array}{l}\text { After an initial weight loss } \\
\text { program, the following results are } \\
\text { presented: Based on the studies, it } \\
\text { seems that an actual increase in } \\
\text { energy expenditure of physical } \\
\text { activity of approximately } 1,500- \\
2,000 \text { kcal/week was associated } \\
\text { with improved weight } \\
\text { maintenance. Nevertheless, } \\
\text { adherence to a prescribed exercise } \\
\text { program remains a big challenge } \\
\text { and is a basic assumption for } \\
\text { weight loss by exercise. } \\
\text { Subjects without exercise training } \\
\text { regained body weight by } 0.28-0.33 \\
\text { kg per week. }\end{array}$ \\
\hline
\end{tabular}

BMI - Body Mass Index; D - diet; DB - database; h - hour; I - Interventions; $\mathrm{k}$ - number of studies; kcal - kilocalories; kg - kilograms; kg/m² - kilograms per squared meter; $\mathrm{M}$ medication; MA - metaanalysis; min - minimum; $\mathrm{n}$ - number of subjects; $\mathrm{S}$ - sugery; no i. - no Information; d - day; e.g. - for example; \% - percent; > - greater then. 
period of the reviews took place up to the year 2003, so that in fact no publication from 2004 to 2006 was considered. Also the choice of databases differed from one to 13 databases. At the least, the questionings of the publications contrasted. Only five publications analyzed the interventions "exercise", "dietary advice" and/ or "only exercise" [5, 9, 10, $12,16]$. A detailed inspection of these meta-analyses showed that the intervention "only exercise" was mostly composed of overweight subjects $\left(25-30 \mathrm{~kg} / \mathrm{m}^{2}\right)$.

To be able to estimate the current state-of-the-art in metaanalysis, a new meta-analysis should be initiated and evaluated. The questioning should be phrased "Effects of physical exercise and/ or diet in overweight and obese subjects on reducing weight, fat and improving physical capacity" and all medicine, exercise and psychology relevant databases should be included in the extensive research. Also the inclusion of subjects with further diseases should be avoided.

\section{META-ANALYSIS}

Most studies found in our search for the meta-analysis evaluated weight loss programs according to their effectiveness, but the scientific procedures used were often insufficiently described [11]. The objective of this metaanalysis is to determine the general effectiveness of the different treatments "diet (d)", "physical exercise (pe)", "diet and physical exercise (dpe)", and "no intervention (ni)" for inducing weight loss in overweight and obese adults without any further illnesses by reviewing randomized controlled trials.

\subsection{Methodology}

This paper is a systematic review of all literature on physical exercise in overweight and obese adults without further orthopedic illnesses published in German and English between 1993 and 2006. We restricted our search to studies examining the effects of physical exercise, diet, or a combination of physical exercise and diet on overweight (BMI 25 - 29) and obese (BMI $\geq 30$ ) adults compared to overweight and obese controls where no intervention was undertaken.

Eleven search words were drawn from the category "indications", seventeen from the category "populations", and 35 from the category "treatments". Thus a total of 6,545 word combinations were used to search the following databases: the Cochrane Controlled Trials Register (CCTR), Dissertation Abstracts, EMBASE, MEDLINE, Psyndex, Psycinfo, and Sport Discus. Out of the 36,819 abstracts found, two independent reviewers selected studies for inclusion in the meta-analysis based on the criteria described below. Effect size was calculated according to the SchmidtHunter method (random effects model calculation) using the meta-analysis software META Version 5.3 [23-25].

To lower the bias, only studies were considered for inclusion in this survey that examined the effects exercise, diet, or a combination of both in at least two concurrent treatment groups consisting of adults (ranging from 17 to 68 years of age) who had been diagnosed as overweight or obese and had a BMI over 25 [26]. Furthermore, studies had to be conducted as randomized controlled trials following the principles of evidence-based medicine. Also the intervention had to have two tests with a treatment in-between. All other studies were excluded. Follow-up and recidivism were not analyzed.

The following parameters were included in the metaanalysis: changes in weight, changes in absolute body fat, changes in body fat percentage, and/ or changes in aerobic capacity (maximal oxygen uptake). The independent variables were "d", "pe", "dpe", and "ni". The dependent variables were changes in weight, absolute body fat and body fat percentage, and aerobic capacity.

Two reviewers independently assessed the quality and eligibility of studies for inclusion in the meta-analysis to achieve an independent and double data collection. In a first step, a brief review of the abstracts reduced the number of potential candidates from 36,869 to 337 . These 337 papers were read in full, and in many cases, the authors were contacted and asked to clarify their data, as studies frequently did not adequately describe the subjects or the method of randomization used. In the end, sixteen randomized controlled trails "RCTs" were identified that fulfilled the criteria described above, three of which were identical and therefore eliminated. Thus the meta-analysis includes a total of thirteen studies [27-39] (Fig. 1).

\subsection{Description of Sample}

All studies included were designed in a pre/post testing format and were based on randomized, controlled trials. The papers, of which twelve were written in English and one in German, were published in the Journal of Psychosomatic Research, Hypertension, Archives of Physical Medicine, Medicine \& Science in Sport \& Exercise, Journal of Aging and Physical Activity, International Journal of Obesity, Journal of the American College of Nutrition, Journal of the American Dietetic Association, Archives of Internal Medicine Journal of the American Medical Association, Ernaehrungs-Umschau, and Physiological Research between 1995 and 2006. The thirteen primary studies included 826 adults between 17 and 68 years of age. Six studies included female subjects only and two studies exclusively male subjects; the overall gender distribution of the study subjects (BMI $>25$ ) was $80 \%$ female and $20 \%$ male [26]. The duration of treatment ranged from four to 72 weeks; exercise frequency varied between two and five times per week. In five studies, the prescribed physical activity consisted of walking; exercise comprised a combination of walking, jogging, bicycle ergometer training, and strength training in six of the studies; two studies allowed subjects a choice between dancing and endurance training. The thirteen studies included a total of 34 different treatment groups. The studies monitored training intensity for the treatment "pe" in a variety of ways: according to heart rate intensity $(50 \%$ to $90 \%$ of maximum heart rate) in five studies [27-31]; according to maximum heart rate reserve (HRR), with intensities from $50 \%$ to $80 \%$, in three studies [32-34]; one study used heart rate reserve (HRR) and maximum oxygen uptake $\left(\mathrm{V}_{2} \mathrm{O}_{2 \max }\right)$ values [35]; one study monitored intensity on the basis of maximal wattage $\left(\mathrm{W}_{\max }\right)$ [36]; and three studies relied on subjective parameters [37-39]. All primary studies reviewed demonstrated that diet and exercise, both alone and in combination, had positive effects, regardless of the duration of treatment, size of the sample, and 


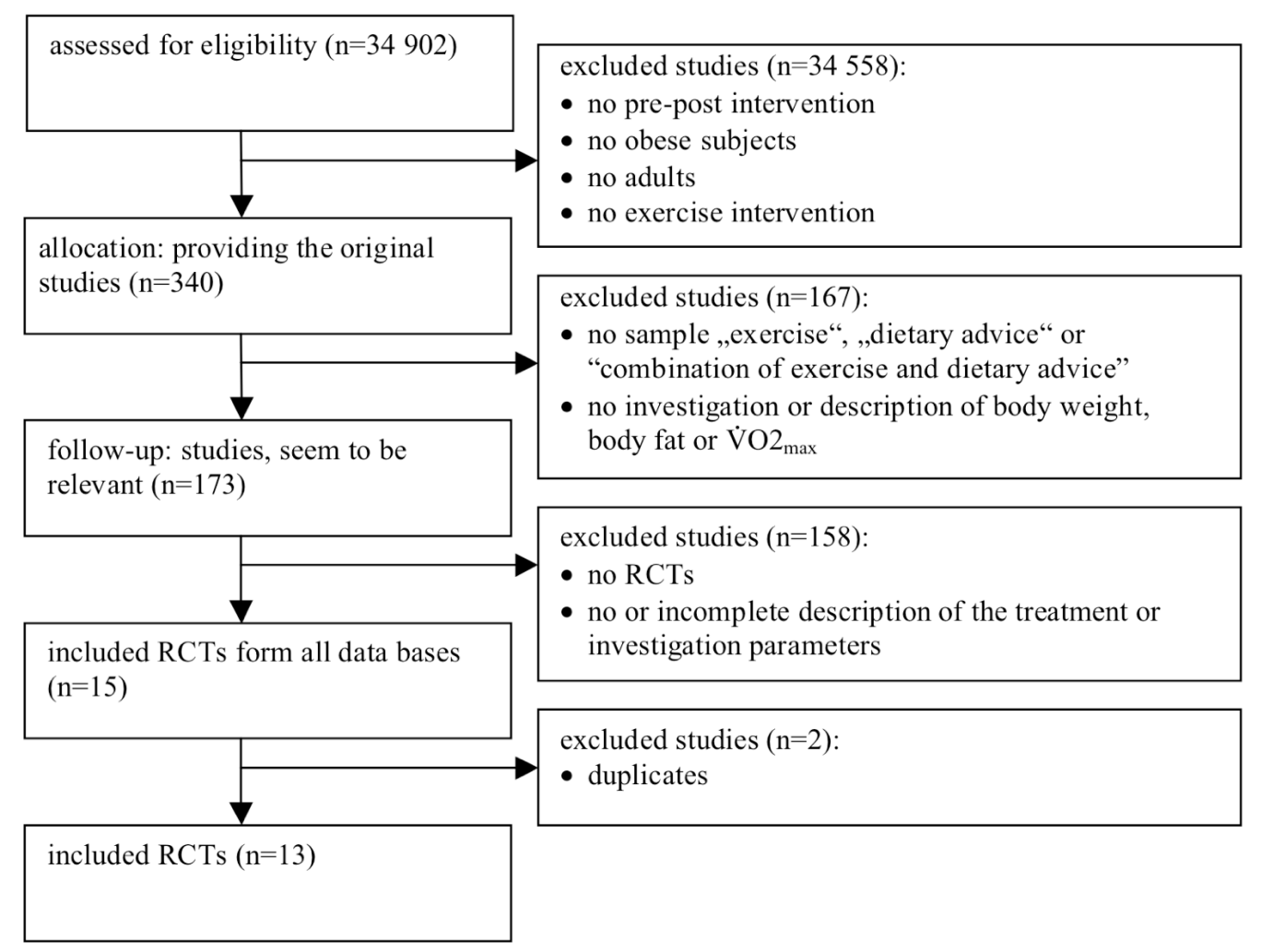

Fig. (1). QUOROM-Flowchart of included RCTs.

methodology used (Tables 2 and 3). Nevertheless, the calculation of the meta-analysis can be performed with the random effect method by Schmidt \& Hunter [23-25], which determines the effect sizes and compares the results afterwards.

\subsection{Results}

The effects of physical exercise only, changes in diet only, and physical exercise and changes in diet combined in overweight and obese adults were analyzed with regard to the question posed by the meta-analysis. The measurements were recorded before and after intervention and compared with the outcome when no intervention took place. A subanalysis was not conducted because of the small size of the sample. The main finding was that a combination of changes in diet and physical exercise is most effective in inducing weight loss and changing body composition. The results for the primary outcome measure "change in weight $(\mathrm{kg})$ " were: population effect size $\left(\mathrm{r}_{\mathrm{g}}\right)=0.4(95 \%$ confidence interval $[\mathrm{CI}]=0.39-0.41)$ for " $\mathrm{d}$ " (Table 4); $\mathrm{r}_{\mathrm{g}}=0.47(95 \% \mathrm{CI}=$ 0.16-0.78) for "dpe" (Table 5); $r_{g}=0.08$ (95\% CI $=0.07$ 0.07 ) for "pe" (Table 6); and $r_{g}=0.02(95 \% \mathrm{CI}=0.24-0.24)$ for the control group with "ni" (Table 7). The results for the primary outcome measure "change in body fat $(\mathrm{kg})$ " were: $r_{g}$ $=0.39(95 \% \mathrm{CI}=0.39-0.39)$ for " $\mathrm{d}$ "; $\mathrm{r}_{\mathrm{g}}=0.52(95 \% \mathrm{CI}=$ $0.52-0.52)$ for "dpe"; $r_{g}=0.21(95 \% \mathrm{CI}=0.21-0.21)$ for "pe"; and $r_{g}=-0.03(95 \% \mathrm{CI}=-0.03--0.03)$ for the control group with "ni". The data sets can be regarded as significant, as the population effect sizes $\left(r_{g}\right)$ were twice the residual standard deviation $\left(\mathrm{SD}_{\text {res }}\right)$, with the exception of the control group "ni", where $r_{\mathrm{g}}=-0.03(95 \% \mathrm{CI}=-0.03--0.03)$. All data sets for body fat $(\mathrm{kg})$ were homogeneous, as the $\mathrm{Chi}^{2}$ test revealed no significant differences and the residual standard deviation $\left(\mathrm{SD}_{\text {res }}\right)$ was less than $25 \%$ of the population effect $\left(r_{g}\right)[24,25]$. However, the data sets for weight $(\mathrm{kg})$, body fat percentage, and maximal oxygen uptake were partly heterogeneous; therefore meta-analysis was not possible.

The figures produced by Binomial Effect Size Display (BESD) for weight loss with the intervention " $\mathrm{d}$ " were $0.30 / 0.70$, i.e. the probability that in 100 individuals diet only will result in weight loss is $40 \%$ greater than the probability that no weight loss will result. For the intervention "pe", BESD $(0.46 / 0.54)$ indicated that the probability that physical exercise only will lead to weight loss in 100 individuals is only $8 \%$ higher than the probability that weight loss will occur when no intervention at all is undertaken. The data set for weight $(\mathrm{kg})$ was heterogeneous for "dpe". "ni" resulted in a mere $2 \%$ probability of weight loss (BESD: $0.49 / 0.51)$. The probability that body fat $(\mathrm{kg})$ will be reduced by " $\mathrm{d}$ " is $40 \%$ (BESD: $0.30 / 0.70$ ); $20 \%$ that a decrease will result from "pe" (BESD: 0.40/0.60); and 52\% that absolute body fat will decrease as a result of "dpe" combined (BESD: 0.24/0.76). "ni" produced a negative effect of $-4 \%$ (BESD: 0.52/0.48). The data set for body fat percentage was heterogeneous for " $d$ " as well as "dpe". The results indicated a $20 \%$ greater probability that body fat percentage will decrease as a result of "pe" than that no decrease will result $(0.40 / 0.60)$; the probability of improvement as a result of "dpe" is $56 \%$ greater than that of no improvement $(0.22 / 0.78)$; and the probability of improvement with "ni" $(0.43 / 0.57)$ is $14 \%$ greater than no improvement. The probability of an increase in the parameter maximum oxygen uptake $\left(\dot{\mathrm{VO}}_{2 \max }\right)$ with "ni" was minus $22 \%$ $(0.61 / 0.39)$. The data set for $\dot{\mathrm{V}} \mathrm{O}_{2 \max }$ was heterogeneous for 
Table 2. Characteristics of Subjects in Studies Included in the Meta-Analysis

\begin{tabular}{|c|c|c|c|c|c|}
\hline Study & Age (in Years) & Patients & BMI & Gender & Measurements \\
\hline $\begin{array}{l}\text { Berg et al. }(2003 ; \\
2005)[38,41]\end{array}$ & $\begin{array}{c}35-65 \\
\mathrm{TG}_{1}: 49.2 \pm 7.72 \\
\mathrm{TG}_{2}: 45.6 \pm 7.01 \\
\mathrm{TG}_{3}: 47.4 \pm 7.63\end{array}$ & $\begin{array}{l}\mathrm{TG}_{1}: \mathrm{n}=28 \\
\mathrm{TG}_{2}: \mathrm{n}=28 \\
\mathrm{TG}_{3}: \mathrm{n}=27\end{array}$ & $\begin{array}{l}\mathrm{TG}_{1}: 32.8 \pm 2.37 \\
\mathrm{TG}_{2}: 31.5 \pm 2.16 \\
\mathrm{TG}_{3}: 31.4 \pm 2.62\end{array}$ & - & $\begin{array}{c}\mathrm{W}_{\max ,} \mathrm{BMI}, \\
\text { body composition, } \\
\text { profile of risk factors }\end{array}$ \\
\hline $\begin{array}{l}\text { Bond Brill et al. } \\
\text { (2002) [39] }\end{array}$ & $\begin{array}{c}\mathrm{TG}_{1(\mathrm{CG})}: 40.1 \pm 1.5 \\
\mathrm{TG}_{2}: 38.7 \pm 1.6 \\
\mathrm{TG}_{3}: 39.7 \pm 1.9\end{array}$ & $\begin{array}{c}\mathrm{TG}_{1(\mathrm{CG})}: \mathrm{n}=16 \\
\mathrm{TG}_{2}: \mathrm{n}=21 \\
\mathrm{TG}_{3}: \mathrm{n}=19\end{array}$ & $\begin{array}{c}\mathrm{TG}_{1(\mathrm{CG})}: 32,79 \pm 1.48 \\
\mathrm{TG}_{2}: 35.27 \pm 1.76 \\
\mathrm{TG}_{3}: 33.76 \pm 1.37\end{array}$ & $\mathrm{f}$ & $\begin{array}{l}\dot{\mathrm{V}} \mathrm{O}_{2 \max } \text {, hydrodensitometry body } \\
\text { density, girth, hip-to-waist ratio }\end{array}$ \\
\hline $\begin{array}{c}\text { Bryner et al. (1997) } \\
{[27]}\end{array}$ & $\begin{array}{l}\mathrm{TG}_{1}: 24.9 \pm 4.6 \\
\mathrm{TG}_{2}: 24.2 \pm 6.0\end{array}$ & $\begin{array}{l}\mathrm{TG}_{1}: \mathrm{n}=7 \\
\mathrm{TG}_{2}: \mathrm{n}=8\end{array}$ & $>25$ & $\mathrm{f}$ & $\begin{array}{c}\dot{\mathrm{VO}}_{2 \max }, \\
\text { hydrostatic weighing }\end{array}$ \\
\hline $\begin{array}{l}\text { Colak and Ozcelik } \\
\qquad(2004)[36]\end{array}$ & $\begin{array}{c}\mathrm{TG}_{1}: 38.3 \pm 10 \\
\mathrm{TG}_{2}: 37.5 \pm 8\end{array}$ & $\begin{array}{l}\mathrm{TG}_{1}: \mathrm{n}=12 \\
\mathrm{TG}_{2}: \mathrm{n}=12\end{array}$ & $\begin{array}{l}\mathrm{TG}_{1}: 36.1 \pm 3.6 \\
\mathrm{TG}_{2}: 39.8 \pm 5.4\end{array}$ & $21 \mathrm{f} / 3 \mathrm{~m}$ & $\mathrm{~W}_{\max }$, BIA (leg-to-leg) \\
\hline $\begin{array}{l}\text { Donnelly et al. (2000) } \\
{[35]}\end{array}$ & $\begin{array}{l}\mathrm{TG}_{1}: 54.0 \pm 9.0 \\
\mathrm{TG}_{2}: 49.0 \pm 8.0\end{array}$ & $\begin{array}{l}\mathrm{TG}_{1}: \mathrm{n}=11 \\
\mathrm{TG}_{2}: \mathrm{n}=11\end{array}$ & $\begin{array}{l}\mathrm{TG}_{1}: 30.12 \pm 2.52 \\
\mathrm{TG}_{2}: 32.33 \pm 5.11\end{array}$ & $\mathrm{f}$ & $\begin{array}{l}\dot{\mathrm{VO}}_{2 \max }, \\
\text { hydrostatic weighing, girth, hip- } \\
\text { to-waist ratio }\end{array}$ \\
\hline $\begin{array}{l}\text { Donnelly et al. (2003) } \\
{[33]}\end{array}$ & $\begin{array}{c}\text { TG: } 24.0 \pm 5.0(\mathrm{f}) \\
22.0 \pm 4.0(\mathrm{~m}) \\
\text { CG: } 21.0 \pm 4.0(\mathrm{f}) \\
24.0 \pm 4.0(\mathrm{~m})\end{array}$ & $\begin{array}{l}\mathrm{TG}_{1}: \mathrm{n}=41 \\
\mathrm{CG}: \mathrm{n}=33\end{array}$ & $\begin{array}{c}\text { TG: } 28.7 \pm 3.2(\mathrm{f}) \\
29.7 \pm 2.9(\mathrm{~m}) \\
\text { CG: } 29.3 \pm 2.3(\mathrm{f}) \\
29.0 \pm 3.0(\mathrm{~m})\end{array}$ & $\mathrm{f}$ & $\begin{array}{c}\dot{\mathrm{V}} \mathrm{O}_{2 \max }, \text { hydrostatic weighing, } \\
\mathrm{CT}\end{array}$ \\
\hline $\begin{array}{l}\text { Gillett et al. (1996) } \\
\qquad[32]\end{array}$ & $\begin{array}{c}64.4 \pm 3.0 \\
\mathrm{TG}_{1}: \text { not specified } \\
\mathrm{TG}_{2}: \text { not specified } \\
\text { CG: not specified }\end{array}$ & $\begin{array}{l}\mathrm{TG}_{1}: \mathrm{n}=63 \\
\mathrm{TG}_{2}: \mathrm{n}=70 \\
\mathrm{CG}: \mathrm{n}=31\end{array}$ & $\begin{array}{c}32.0 \pm 4.0 \\
\mathrm{TG}_{1}: \text { not specified } \\
\mathrm{TG}_{2}: \text { not specified } \\
\mathrm{CG}: \text { not specified }\end{array}$ & $\mathrm{f}$ & $\dot{\mathrm{V}} \mathrm{O}_{2 \max }$, skinfold thickness \\
\hline $\begin{array}{c}\text { Jakicic et al. (1999) } \\
\text { [37] }\end{array}$ & $\begin{array}{l}\mathrm{TG}_{1}: 37.2 \pm 6.2 \\
\mathrm{TG}_{2}: 36.7 \pm 4.6 \\
\mathrm{TG}_{3}: 37.5 \pm 5.5\end{array}$ & $\begin{array}{l}\mathrm{TG}_{1}: \mathrm{n}=49 \\
\mathrm{TG}_{2}: \mathrm{n}=51 \\
\mathrm{TG}_{3}: \mathrm{n}=48\end{array}$ & $\begin{array}{l}\mathrm{TG}_{1}: 32.9 \pm 3.8 \\
\mathrm{TG}_{2}: 33.2 \pm 4.0 \\
\mathrm{TG}_{3}: 32.2 \pm 4.3\end{array}$ & $\mathrm{f}$ & $\dot{\mathrm{V} \mathrm{O}_{2 \max }}$, girth, hip-to-waist ratio \\
\hline $\begin{array}{c}\text { Kraemer et al. (1999) } \\
{[30]}\end{array}$ & $\begin{array}{l}\mathrm{TG}_{1}: 40.0 \pm 6.3 \\
\mathrm{TG}_{2}: 37.8 \pm 8.5 \\
\mathrm{TG}_{3}: 39.9 \pm 6.4 \\
\mathrm{CG}: 30.3 \pm 7.4\end{array}$ & $\begin{array}{c}\mathrm{TG}_{1}: \mathrm{n}=8 \\
\mathrm{TG}_{2}: \mathrm{n}=11 \\
\mathrm{TG}_{3}: \mathrm{n}=10 \\
\mathrm{CG}: \mathrm{n}=6\end{array}$ & $\begin{array}{l}\mathrm{TG}_{1}: 33.1 \pm 4.3 \\
\mathrm{TG}_{2}: 31.3 \pm 3.1 \\
\mathrm{TG}_{3}: 29.2 \pm 2.9 \\
\mathrm{CG}: 27.9 \pm 2.3 \\
\end{array}$ & $\mathrm{~m}$ & $\dot{\mathrm{V}} \mathrm{O}_{2 \max }$, hydrostatic weighing \\
\hline $\begin{array}{l}\text { Leutholtz et al. (1995) } \\
\qquad[34]\end{array}$ & $\begin{array}{l}\mathrm{TG}_{1}: 43.5 \pm 7.8 \\
\mathrm{TG}_{2}: 39.8 \pm 7.3\end{array}$ & $\begin{array}{l}\mathrm{TG}_{1}: \mathrm{n}=20 \\
\mathrm{TG}_{2}: \mathrm{n}=20\end{array}$ & $>25$ & $33 \mathrm{f}, 7 \mathrm{~m}$ & $\dot{\mathrm{V}} \mathrm{O}_{2 \max }, \mathrm{BIA}$ \\
\hline $\begin{array}{l}\text { Miller et al. (2002) } \\
\qquad[31]\end{array}$ & $\begin{array}{l}\text { TG: } 53.0 \pm 11.0 \\
\text { CG: } 54.0 \pm 8.0\end{array}$ & $\begin{array}{l}\text { TG: } 22 \\
\text { CG: } 23\end{array}$ & $\begin{array}{l}\text { TG: } 32.8 \pm 5.4 \\
\text { CG: } 34.2 \pm 6.2\end{array}$ & $28 \mathrm{f}, 17 \mathrm{~m}$ & HR, RPE, BMI \\
\hline $\begin{array}{l}\text { Niemann et al. }(2000) \\
{[29]}\end{array}$ & $\begin{array}{c}45.6 \pm 1.1 \\
\mathrm{TG}_{1}: \text { not specified } \\
\mathrm{TG}_{2}: \text { not specified } \\
\mathrm{TG}_{3}: \text { not specified } \\
\mathrm{CG}: \text { not specified }\end{array}$ & $\begin{array}{l}\mathrm{TG}_{1}: \mathrm{n}=21 \\
\mathrm{TG}_{2}: \mathrm{n}=26 \\
\mathrm{TG}_{3}: \mathrm{n}=22 \\
\mathrm{CG}: \mathrm{n}=22\end{array}$ & $\begin{array}{c}33.1 \pm 0.62 \\
\mathrm{TG}_{1}: \text { not specified } \\
\mathrm{TG}_{2}: \text { not specified } \\
\mathrm{TG}_{3}: \text { not specified } \\
\text { CG: not specified }\end{array}$ & $\mathrm{f}$ & $\dot{\mathrm{V}} \mathrm{O}_{2 \max }$, hydrostatic weighing \\
\hline $\begin{array}{l}\text { Pritchard et al. (1997) } \\
{[28]}\end{array}$ & $\begin{array}{c}\mathrm{TG}_{1}: 42.3 \pm 4.5 \\
\mathrm{TG}_{2}: 43.6 \pm 18.0 \\
\mathrm{CG}: 44.9 \pm 6.5\end{array}$ & $\begin{array}{l}\mathrm{TG}_{1}: \mathrm{n}=18 \\
\mathrm{TG}_{2}: \mathrm{n}=21 \\
\mathrm{CG}: \mathrm{n}=19\end{array}$ & $\begin{array}{l}\mathrm{TG}_{1}: 29.0 \pm 2.8 \\
\mathrm{TG}_{2}: 29.2 \pm 2.8 \\
\mathrm{CG}: 44.9 \pm 6.5\end{array}$ & $\mathrm{~m}$ & $\begin{array}{l}\text { Index of activity, X-ray } \\
\text { densitometer, DEXA }\end{array}$ \\
\hline
\end{tabular}

BIA - bioelectrical impedance plethysmography; BMI - Body Mass Index; HR - heart rate; HRR - heart rate reserve; kcal - kilocalorie; CG - control group; $f$ - female; $m$ - male; max - maximum; min - minutes; $\mathrm{N}$ - group (total); $\mathrm{n}$ - subgroup; $\mathrm{TG}$ - treatment group; $\dot{\mathrm{V}} \mathrm{O}_{2 \max }$ - maximum oxygen uptake.

the groups "d", "pe", and "dpe" $[24,25]$; therefore, metaanalysis was not possible.

In summary, the interventions " $\mathrm{d}$ " and "dpe" had the greatest effect with regard to weight loss; the greatest decrease in absolute body fat and body fat percentage resulted through "dpe". A particularly noteworthy finding was the negative effect of "ni" on aerobic capacity.

\subsection{Discussion}

The large number of hits obtained in the databases is remarkable, though a high initial outcome was inevitable as the search was very detailed. The data were drawn from studies published between 1993 and 2006 that were 
Table 3. Results Regarding the Effects of Exercise of the Studies Included in the Meta-Analysis

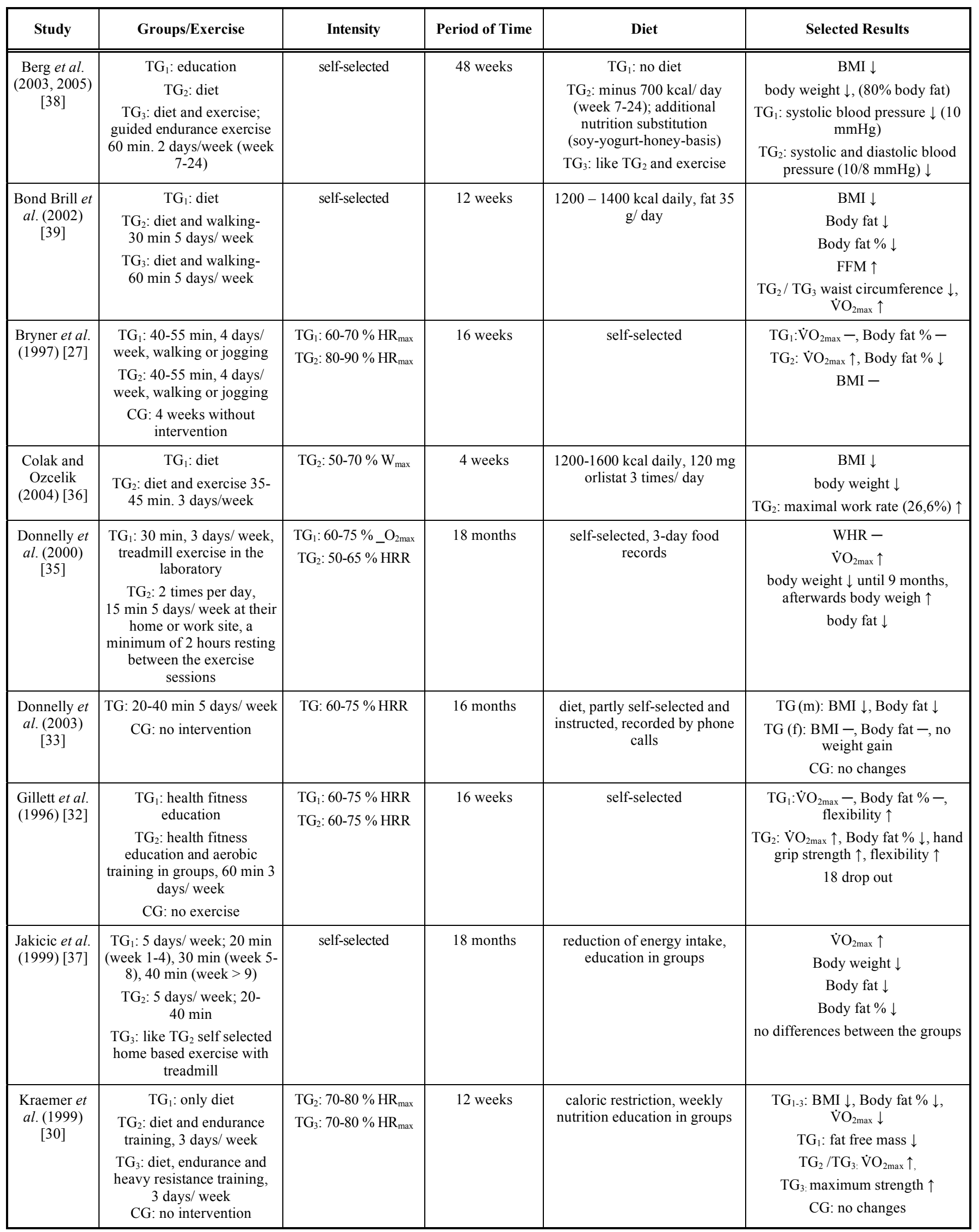




\begin{tabular}{|c|c|c|c|c|c|}
\hline Study & Groups/Exercise & Intensity & Period of Time & Diet & Selected Results \\
\hline $\begin{array}{l}\text { Leutholtz et } \\
\text { al. (1995) } \\
\text { [34] }\end{array}$ & $\begin{array}{l}\mathrm{TG}_{1} \text { : exercise, } 3 \text { days/ week } \\
\mathrm{TG}_{2} \text { : exercise, } 3 \text { days/ week }\end{array}$ & $\begin{array}{l}\mathrm{TG}_{1}: 60 \% \mathrm{HRR} \\
\mathrm{TG}_{2}: 40 \% \mathrm{HRR}\end{array}$ & 12 weeks & $\begin{array}{c}\text { caloric restriction - Opifast } \\
(420 \mathrm{kcal} / \text { day, } 5 \text { days/ week })\end{array}$ & $\begin{array}{c}\text { BMI } \downarrow \\
\text { Body weight } \downarrow \\
\text { Body fat } \downarrow \\
\dot{V}_{2 \max } \uparrow \\
\text { no differences between the groups }\end{array}$ \\
\hline $\begin{array}{l}\text { Miller et al. } \\
(2002)[31]\end{array}$ & $\begin{array}{l}\text { TG: regular aerobic exercise } \\
30-45 \text { min, } 3 \text { days/ week } \\
\text { (treadmill and bicycle } \\
\text { ergometer training, walking } \\
\text { in stadium) } \\
\text { CG: no intervention }\end{array}$ & $50-75 \% \mathrm{HR}_{\max }$ & 9 weeks & TG: DASH Diet & $\begin{array}{c}\text { TG: body weight } \downarrow \text {, BMI } \downarrow \text {, HR } \downarrow \\
\text { CG: no changes }\end{array}$ \\
\hline $\begin{array}{l}\text { Niemann } e t \\
\text { al. }(2000) \\
\quad[29]\end{array}$ & $\begin{array}{c}\mathrm{TG}_{1} \text { : exercise, } 5 \text { days/ week, } \\
20-45 \text { min walking } \\
\mathrm{TG}_{2} \text { : diet } \\
\mathrm{TG}_{3} \text { : exercise and diet - } \\
\text { (like } \mathrm{TG}_{1} \text { and } \mathrm{TG}_{2} \text { ) } \\
\text { CG: } 4 \text { days/ week, } 45 \text { min } \\
\text { Stretching }\end{array}$ & $60-75 \% \mathrm{HR}_{\max }$ & 12 weeks & $\begin{array}{c}\mathrm{TG}_{2}: 1200-1300 \mathrm{kcal} / \text { day } \\
\mathrm{TG}_{3}: 1200-1300 \mathrm{kcal} / \text { day } \\
\text { weekly nutrition education in } \\
\text { groups }\end{array}$ & $\begin{array}{c}\mathrm{TG}_{1} / \mathrm{TG}_{3}: \dot{\mathrm{VO}_{2 \max } \uparrow} \\
\mathrm{TG}_{2} / \mathrm{TG}_{3}: \mathrm{BMI} \downarrow, \text { Body fat } \% \downarrow\end{array}$ \\
\hline $\begin{array}{l}\text { Pritchard et } \\
\text { al. (1997) } \\
\text { [28] }\end{array}$ & $\begin{array}{c}\mathrm{TG}_{1} \text { : diet } \\
\mathrm{TG}_{2}: \text { exercise, } 3 \text { days/ week, } \\
30 \text { min; own aerobic } \\
\text { exercise } \\
\text { CG: monthly weight- } \\
\text { monitoring }\end{array}$ & $65-75 \% \mathrm{HR}_{\max }$ & 12 months & $\begin{array}{c}\text { caloric restriction, information } \\
\text { transfers to The Weight Loss } \\
\text { Guide of the Australian Heart } \\
\text { Foundation }\end{array}$ & $\begin{array}{c}\mathrm{TG}_{1} \text { : Body weight } \downarrow \text { after } 3,6,9 \\
\text { and } 12 \text { month } \\
\mathrm{TG}_{2: \text { Body weight } \downarrow \text { after } 12 \text { month }} \text { CG: no changes }\end{array}$ \\
\hline
\end{tabular}

BIA - bioelectrical impedance plethysmography; BMI - Body Mass Index; HR - heart rate; $\mathrm{HR}_{\max }$ - maximum heart rate; HRR - heart rate reserve; kcal - kilocalorie; CG - control group; f - female; $\mathrm{m}$ - male; max - maximum; min - minutes; $\mathrm{N}$ - group (total); $\mathrm{n}$ - subgroup; $\mathrm{TG}$ - treatment group; $\mathrm{V}_{2} \mathrm{O}_{2 \max }$ - maximum oxygen uptake.

Table 4. Summary of Results Regarding "Diet Only" [19, 28-30, 36, 38]

\begin{tabular}{|c|c|c|c|c|c|c|c|c|c|c|c|}
\hline Only Diet & $\mathbf{N}$ & $\mathbf{k}$ & $\mathbf{r}_{\mathrm{g}}$ & $95 \% \mathrm{CI}$ & $\mathbf{S}_{\mathrm{r}}^{2}$ & $\mathrm{~S}_{\text {rho }}^{2}$ & $\% \mathrm{SE}$ & $\mathbf{S D}_{\text {res }}$ & $\mathbf{C h i}^{2}$ & BESD & $\mathbf{g}$ \\
\hline Body weight $(\mathrm{kg})$ & 107 & 6 & 0.401 & $0.388-0.413$ & 0.04 & 0.04 & 99.9 & -0.0004 & $\mathrm{p}=0.306$ & $0.30 / 0.70$ & 0.7 \\
\hline Body fat (\%) & 77 & 4 & 0.544 & $0.148-0.939$ & 0.066 & 0.026 & 38.80 & 0.041 & $\mathrm{p}=0.016$ & $0.23 / 0.77$ & 1.295 \\
\hline $\begin{array}{l}\text { Maximal oxygen uptake } \\
\left(\dot{\mathrm{V}}_{2 \max }\right)(\mathrm{ml} / \mathrm{min} / \mathrm{kg})\end{array}$ & 24 & 2 & 0.182 & $-0.672-1.036$ & 0.268 & 0.078 & 29.09 & 0.19 & $\mathrm{p}=0.009$ & $0.41 / 0.59$ & 0.371 \\
\hline
\end{tabular}

BESD - Binomial Effect Size Display; g - standardized mean differences; k - number of groups; $95 \%$ CI - 95\% confidence interval of population effect sizes; $\mathrm{N}$ - subjects (total); $\mathrm{Chi}^{2}$ - significance of $\chi^{2}$ (test of homogeneity); $\mathrm{r}_{\mathrm{g}}$ - population effect size (weighted mean); $\mathrm{SD}_{\mathrm{res}}$ - residual standard deviation; \%SE - random samples within monitored variance; $\mathrm{s}_{\mathrm{r}}^{2}$ variance of effect size $\mathrm{r}_{\mathrm{g}} ; \mathrm{s}_{\text {rho }}^{2}$ - residual variance; $\dot{\mathrm{V}}_{2 \max }$ - maximum oxygen uptake.

Table 5. Summary of Results Regarding "Physical Exercise and Diet" [19, 29-31, 34, 36, 38]

\begin{tabular}{|c|c|c|c|c|c|c|c|c|c|c|c|}
\hline $\begin{array}{l}\text { Combination of Physical } \\
\text { Exercise and Diet }\end{array}$ & $\mathbf{N}$ & $\mathbf{k}$ & $\mathbf{r}_{\mathrm{g}}$ & $95 \%$ CI & $\mathbf{S}_{\mathrm{r}}^{2}$ & $\mathbf{S}_{\text {rho }}^{2}$ & $\% \mathrm{SE}$ & $\mathbf{S D}_{\text {res }}$ & $\mathrm{Chi}^{2}$ & BESD & g \\
\hline Body weight (kg) & 184 & 9 & 0.472 & $0.162-0.781$ & 0.055 & 0.03 & 54.23 & 0.025 & $\mathrm{p}=0.035$ & $0.26 / 0.74$ & 1.07 \\
\hline Body fat (kg) & 140 & 7 & 0.52 & $0.52-0.52$ & 0.017 & 0.027 & 100 & -0.01 & $\mathrm{p}=0.627$ & $0.24 / 0.76$ & 1.217 \\
\hline Body fat (\%) & 129 & 6 & 0.564 & $0.277-0.851$ & 0.043 & 0.022 & 50.18 & 0.021 & $\mathrm{p}=0.035$ & $0.22 / 0.78$ & 1.366 \\
\hline 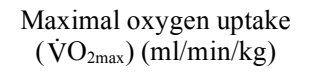 & 61 & 4 & -0.660 & $-0.66--0.66$ & 0.013 & 0.021 & 100.00 & -0.008 & $\mathrm{p}=0.468$ & $0.83 / 0.17$ & -1.760 \\
\hline
\end{tabular}

BESD - Binomial Effect Size Display; g - standardized mean differences; $\mathrm{k}$ - number of groups; $95 \%$ CI - 95\% confidence interval of population effect sizes; $\mathrm{N}$ - subjects (total); $\mathrm{Chi}^{2}$ - significance of $\chi^{2}$ (test of homogeneity); $\mathrm{r}_{\mathrm{g}}$ - population effect size (weighted mean); $\mathrm{SD}_{\mathrm{res}}$ - residual standard deviation; \%SE - random samples within monitored variance; $\mathrm{s}_{\mathrm{r}}^{2}$ variance of effect size $\mathrm{r}_{\mathrm{g}} ; \mathrm{s}_{\text {rho }}^{2}$ - residual variance; $\dot{\mathrm{V}} \mathrm{O}_{2 \max }$ - maximum oxygen uptake.

conducted with different kinds of subjects to create parallelism structure of different programs; exercise duration ranged from ten minutes daily [2, 14] up to 280 and more minutes per week [9]. The studies reviewed were narrowly 
Table 6. Summary of Results Regarding "Physical Exercise Only" [27-29, 32, 33, 35, 37]

\begin{tabular}{|c|c|c|c|c|c|c|c|c|c|c|c|}
\hline Exercise Only & $\mathbf{N}$ & $\mathbf{k}$ & $\mathbf{r}_{\mathrm{g}}$ & $95 \%$ CI & $\mathbf{S}^{2}{ }_{r}$ & $\mathbf{S}_{\text {rho }}^{2}$ & $\% \mathrm{SE}$ & $\mathbf{S D}_{\text {res }}$ & $\mathbf{C h i}^{2}$ & BESD & g \\
\hline Body weight (kg) & 238 & 8 & 0.079 & $0.074-0.074$ & 0.005 & 0.033 & 100 & -0.028 & $\mathrm{p}=0.990$ & $0.46 / 0.54$ & 0.148 \\
\hline Body fat (kg) & 232 & 8 & 0.207 & $0.207-0.207$ & 0.009 & 0.032 & 100 & -0.023 & $\mathrm{p}=0.944$ & $0.40 / 0.60$ & 0.424 \\
\hline Body fat (\%) & 380 & 12 & 0.205 & $0.205-0.205$ & 0.008 & 0.029 & 100 & -0.021 & $\mathrm{p}=0.986$ & $0.40 / 0.60$ & 0.418 \\
\hline $\begin{array}{l}\text { Maximal oxygen uptake } \\
\left(\dot{\mathrm{V}}_{2 \max }\right)(\mathrm{ml} / \mathrm{min} / \mathrm{kg})\end{array}$ & 189 & 6 & -0.420 & $-0.751-0.084$ & 0.051 & 0.022 & 42.77 & 0.029 & $\mathrm{p}=0.015$ & $0.71 / 0.29$ & -0.92 \\
\hline
\end{tabular}

BESD - Binomial Effect Size Display; g - standardized mean differences; k - number of groups; $95 \%$ CI - 95\% confidence interval of population effect sizes; N - subjects (total); $\mathrm{Chi}^{2}$ - significance of $\chi^{2}$ (test of homogeneity); $\mathrm{r}_{\mathrm{g}}$ - population effect size (weighted mean); $\mathrm{SD}_{\mathrm{res}}$ - residual standard deviation; \% $\mathrm{SE}$ - random samples within monitored variance; $\mathrm{s}_{\mathrm{r}}$ variance of effect size $\mathrm{r}_{\mathrm{g}} ; \mathrm{s}^{2}$ rho - residual variance; $\dot{\mathrm{V}} \mathrm{O}_{2 \max }-$ maximum oxygen uptake.

Table 7. Summary of Results Regarding "No Intervention” [28-31, 33]

\begin{tabular}{|c|c|c|c|c|c|c|c|c|c|c|c|}
\hline No Intervention & $\mathbf{N}$ & $\mathbf{k}$ & $\mathbf{r}_{\mathrm{g}}$ & $95 \%$ CI & $\mathbf{S}^{2}{ }_{\mathrm{r}}$ & $\mathbf{S}_{\text {rho }}^{2}$ & $\% \mathrm{SE}$ & $\mathbf{S D}_{\text {res }}$ & $\mathrm{Chi}^{2}$ & BESD & g \\
\hline Body weight $(\mathrm{kg})$ & 134 & 7 & 0.024 & $0.244-0.244$ & 0.010 & 0.052 & 100 & -0.043 & $\mathrm{p}=0.970$ & $0.49 / 0.51$ & 0.050 \\
\hline Body fat (kg) & 58 & 4 & -0.032 & $-0.032--0.032$ & 0.011 & 0.069 & 100 & -0.058 & $\mathrm{p}=0.635$ & $0.52 / 0.48$ & -0.063 \\
\hline Body fat $(\%)$ & 92 & 5 & 0.136 & $0.136-0.136$ & 0.041 & 0.052 & 100 & -0.012 & $\mathrm{p}=0.422$ & $0.43 / 0.57$ & 0.274 \\
\hline $\begin{array}{l}\text { Maximal oxygen uptake } \\
\left(\dot{\mathrm{V}} \mathrm{O}_{2 \max }\right)(\mathrm{ml} / \mathrm{min} / \mathrm{kg})\end{array}$ & 64 & 3 & -0.218 & $-0.220--0.220$ & 0.002 & 0.043 & 100 & -0.040 & $\mathrm{p}=0.931$ & $0.61 / 0.39$ & -0.450 \\
\hline
\end{tabular}

BESD - Binomial Effect Size Display; g - standardized mean differences; k - number of groups; 95\% CI - 95\% confidence interval of population effect sizes; N - subjects (total); $\mathrm{Chi}^{2}$ - significance of $\chi^{2}$ (test of homogeneity); $\mathrm{r}_{\mathrm{g}}$ - population effect size (weighted mean); $\mathrm{SD}_{\mathrm{res}}$ - residual standard deviation; \% $\mathrm{SE}$ - random samples within monitored variance; $\mathrm{s}_{\mathrm{r}}^{2}$ variance of effect size $\mathrm{r}_{\mathrm{g}} ; \mathrm{s}_{\text {rho }}^{2}$ - residual variance; $\dot{\mathrm{V}} \mathrm{O}_{2 \max }$ - maximum oxygen uptake.

focused, with relatively few variables (Table 2 ). The subjects ranged from 21 to 54 years of age, with a mean age of 40 . Most of the studies were performed with subjects that were moderately obese; however, the definition of obesity varied in the studies. Body Mass Index (BMI) was the primary criterion, but all authors included overweight (BMI > 25) and obese (BMI $>30)$ subjects in a single study group. Thus, the results could present a distorted picture, as it is conceivable that physical exercise is a more effective intervention strategy for older or more severely obese individuals [11].

In this meta-analysis, we aimed to avoid the pitfalls commonly involved in compiling this kind of systematic review. The electronic literature located depends on the number of databases searched and the search strategy and key words used. In this study, all relevant medical research databases were taken into account; the search strategy covered all medical subject terms ("mesh search") in each database. Selecting the relevant studies from the wealth of titles and abstracts could have presented a problem; this was addressed by utilizing a list of inclusion criteria and having two reviewers independently assess which studies merited inclusion in the meta-analysis. In the end, although the entire references from each paper selected were checked for other possible eligible studies, only thirteen met the criteria, as the meta-analysis was restricted to studies based on randomized controlled trials. Thus, the greatest weakness of this review is the small number of studies involved.

The main result of this meta-analysis is that changes in diet alone or in combination with physical exercise are the most effective courses of treatment when it comes to weight loss and changing body composition, i.e. increasing lean body mass and decreasing body fat (Table 3 ). With regard to the parameters examined, the interventions "d" and "dpe" resulted in greater weight loss than "pe" alone. These results partly confirm the outcomes of earlier reviews.

For example, while the results of the meta-analysis by Garrow \& Summerbell (1995), which included 28 studies published between 1966 and 1993 [19], demonstrated that exercise only could reduce weight by three kilograms in 30 weeks [20], they indicated that a combination of diet and exercise had the greatest effect and that "strength training" had no discernable influence on weight loss.

Miller et al. (1997) performed a meta-analysis of 493 primary studies published from 1969 to 1994 [20]. The objective of the review was to determine the effect of exercise and changes in diet, both alone and in combination, on weight loss; the subjects were middle-aged and moderately overweight rather than obese and the duration of treatment was fairly long, i.e. 15 weeks. The authors found that both changes in diet alone and changes in diet in combination with exercise were more effective in inducing weight loss in short-term interventions than exercise alone. In his review, Wing (1999) confirmed that a combination of exercise and changes in diet produced the best outcome in short-term interventions, while emphasizing the importance of exercise in maintaining and stabilizing weight over the long term [19]. Gleim (1993) asserted that exercise had a beneficial effect in reducing lifestyle diseases in overweight individuals, even when little or no weight loss resulted [13, $18,22]$. Blundell and King found that exercise did not lead to an increase in average daily caloric intake [10]. These results show that dieting is more effective in reducing weight, but that exercise is more effective in reducing fat during the early phase of a weight-reducing program in healthy overweight or obese persons [40-42]. Furthermore, 
adherence is such an important factor that Biddle \& Fox (1998) recommended the utilization of special health consultants to support individuals in weight loss programs $[22,38]$ however the performance of training of the included studies was not described. Also dropouts exert a high influence on the results of the single studies [van Baak]. However, the included studies did not refer to dropout-rates. As to the best kind of exercise, Rippe \& Hess (1998) found that walking had the highest influence to combat obesity, followed by swimming, biking, and low-intensity aerobics $[13,18,40]$.

\section{CONCLUSION}

In conclusion, the data obtained in long-term clinical trials evaluating various methods of weight maintenance are supported by this review of the literature [11]. Though exercise intensity and duration varied, as did the organization of the programs, all studies reviewed found that physical exercise had beneficial effects in overweight and obese subjects. However, when it comes to inducing weight loss, the results indicate that physical exercise combined with changes in diet is the most effective form of treatment. Unfortunately, the information supplied about diet regimens was usually not very detailed. More research to evaluate different strategies for short- and long-term weight loss and weight maintenance programs would be extremely useful.

\section{REFERENCES}

[1] Bundesministerium für Gesundheit (BMG). Daten des Gesundheitswesens - Schriftenreihe des Bundesministeriums für Gesundheit. Baden-Baden: Nomos 1995; vol. 51.

[2] McInnis KJ. Exercise and obesity. Coron Artery Dis 2000; 2: 1116.

[3] Anderson JW, Luan J, Hoie LH. Structured weight-loss programs: meta-analysis of weight loss at 24 weeks and assessment of effects of intervention intensity. Adv Ther 2004; 21: 61-75.

[4] Avenell A, Brown TJ, McGee MA, et al. What are the long-term benefits of weight reducing diets in adults? A systematic review of randomized controlled trails. J Hum Nutr Diet 2004; 17: 317-35.

[5] Douketis JD, Macie C, Thabane L, Williamson DF. Systematic review of long- term weight loss studies in obese adults: Clinical significance and applicability to clinical practice. Int J Obes 2005; 29 (10): 1153-67.

[6] Schrauwen P, Westerterp KR. The role of high-fat diets and physical activity in the regulation of body weight. Br J Nutr 2000; 84(1): 417-27.

[7] Van Baak MA. Exercise training and substrate utilisation in obesity. Int J Obes 1999; 23(Suppl 3): 11-7.

[8] Curioni CC, Lourenço PM. Long-term weight loss after diet and exercise: A systematic review. Int J Obes 2005; 29(5): 1168-74.

[9] Garrow JS, Summerbell CD. Meta-analysis: effect of exercise, with or without dieting, on the body composition of overweight subjects. Eur J Clin Nutr 1995; 1: 1-10.

[10] Blundell JE, King NA. Physical activity and regulation of food intake: current evidence. Med Sci Sports 1999; 2(Suppl): 573-83.

[11] Miller WC, Koceja DM, Hamilton EJ. A meta-analysis of the past 25 years of weight loss research using diet, exercise or diet plus exercise intervention. Int J Obes 1997; 10: 941-7.

[12] Ross R. Effects of diet and exercise-induced weight loss on visceral adipose tissue in men and women. Sports Med 1997; 24(1): 55-64.

[13] Ross R, Freeman JA, Janssen I. Exercise alone is an effective strategy for reducing obesity and related comorbidities. Exerc Sport Sci Rev 2000; 4: 165-70.

[14] Wing RR. Physical activity in the treatment of the adulthood overweight and obesity: current evidence and research issues. Med Sci Sports 1999; 11(Suppl): 47-552.
[15] Avenell A, Brown TJ, McGee, et al. What interventions should we add to weight reducing diets in adults with obesity? A systematic review of randomized controlled trials of adding drug therapy, exercise, behaviour therapy or combinations of these interventions. J Hum Nutr Diet 2004; (17): 293-316.

[16] Shaw K, O'Rourke P, Del Mar C, et al. Psychological interventions for overweight or obesity (Review). Chichester: The Cochrane Collaboration. Chichester: John Wiley \& Sons, Ltd 2006.

[17] Fogelholm M, Kukkonen-Harjula K. Does physical activity prevent weight gain - a systematic review. Obes Rev 2000; 1(7): 95-111.

[18] Biddle SJH, Fox KR. Motivation for physical activity and weight management. Int J Obes 1998; 2(Suppl): 39-47.

[19] Gleim GW. Exercise is not an effective weight loss modality in women. J Am Coll Nutr 1993; 4: 363-7.

[20] Harris JE. The role of physical activity in the management of obesity. J Am Osteopath Assoc 1999; 4(Suppl):15-9.

[21] Jakicic JM, Gallagher KI. Exercise considerations for the sedentary, overweight adult. Exerc Sport Sci Rev 2003; 2: 91-5.

[22] Rippe JM, Hess S. The role of physical activity in the prevention and management of obesity. J Am Diet Assoc 1998; 10(Suppl 2): 31-8.

[23] Hunter JE, Schmidt FL, Jackson G B. Meta-analysis: cumulating research findings across studies. Beverly Hills: Sage 1982.

[24] Hunter JE, Schmidt FL. Methods of meta-analysis. Newbury Park: Sage 1990.

[25] Schwarzer R. Meta-Analysis Programs. Version 5.3. 1989; [cited on 8-7-2006]. Available from: http://userpage.fu-berlin.de/ health/ meta_e.htm

[26] World Health Organisation Technical Report. Obesity: preventing and managing the global epidemic. Report of a WHO consultation. Geneva 2000; 894, I-XII, 1-253.

[27] Bryner RW, Toffle RC, Ullrich IH, et al. The effects of exercise intensity on body composition, weight loss, and dietary composition in women. J Am Coll Nutr 1997; 1: 68-73.

[28] Pritchard JE, Nowson CA, Wark JD. A worksite program for overweight middle-aged men achieves lesser weight loss with exercise than with dietary change. J Am Diet Assoc 1997;1: 37-42.

[29] Nieman DC, Custer WF, Butterworth DE, et al. Psychological response to exercise training and/or energy restriction in obese women. J Psychosom Res 2000; 1: 23-9.

[30] Kraemer WJ, Volek JS, Clark KL. Influence of exercise training on physiological and performance changes with weight loss in men. Med Sci Sports 1999; 9:1320-9.

[31] Miller ER, Erlinger TP, Young DR, et al. Results of the diet, exercise, and weight loss intervention trial (DEW-IT). Hypertension 2002; 5: 612-8.

[32] Gillett PA, White AT, Caserta MS. Effect of exercise and/or fitness education on fitness in older, sedentary, obese women. J Aging Phys Act 1996; 4: 42-55.

[33] Donnelly JE, Hill JO, Jacobsen DJ. Effects of a 16-month randomized controlled exercise trial on body weight and composition in young, overweight men and women. Arch Intern Med 2003; 11: 1343-50.

[34] Leutholtz BC, Keyser RE, Heusner WW, et al. Exercise training and severe caloric restriction: effect on lean body mass in the obese. Arch Phys Med Rehabil 1995;1: 65-70.

[35] Donnelly JE, Jacobsen DJ, Heelan KS, et al. The effects of 18 months of intermittent $v s$ continuous exercise on aerobic capacity, body weight and composition, and metabolic fitness in previously sedentary, moderately obese females. Int J Obes 2000; 5: 566-72.

[36] Colak R, Ozcelik O. Effects of short-period exercise training and orlistat therapy on body composition and maximal power production capacity in obese patients. Physiol Res 2004; 2: 53-60.

[37] Jakicic JM, Winters C, Lang W, et al. Effects of intermittent exercise and use of home exercise equipment on adherence, weight loss, and fitness in overweight women: a randomized trial. JAMA 1999; 16: 1554-60.

[38] Berg A, Frey I, Deibert P, et al. Gewichtsreduktion ist machbar. Ernahr Umsch 2003; 10: 386-92.

[39] Bond BJ, Perry AC, Parker L, et al. Dose-response effect of walking exercise on weight loss. How much is enough? Int J Obes 2002; 11: 1484-93. 
[40] Thorogood M. Combining diet with physical activity in the treatment of obesity. J Hum Nutr Diet 1998; 3: 239-42.

[41] Berg A, Frey I, Landmann U, et al. Gewichtsreduktion durch Lebensstilintervention. Ernahr Umsch 2005; 8: 310-4.
[42] Tsai A, Sandretto A, Chung Y. Dieting is more effective in reducing weight but exercise is more effective in reducing fat during the early phase of a weight-reducing program in healthy humans. J Nutr Biochem 2003; 14(9): 541-9.

(C) Schaar et al.; Licensee Bentham Open.

This is an open access article licensed under the terms of the Creative Commons Attribution Non-Commercial License (http://creativecommons.org/licenses/by-nc/3.0/) which permits unrestricted, non-commercial use, distribution and reproduction in any medium, provided the work is properly cited. 